Prepared for the U.S. Department of Energy

under Contract DE-AC05-76RL01830

\title{
Refractory Glass Seals for SOFC
}

Y.S. "Matt" Chou and J.W. Stevenson

Pacific Northwest National Laboratory, Richland, WA

February 2009 (Released July 2011)

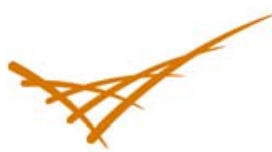

Pacific Northwest

NATIONAL LABORATORY

Proudly Operated by Battelle Since 1965 


\title{
DISCLAIMER
}

This report was prepared as an account of work sponsored by an agency of the United States Government. Neither the United States Government nor any agency thereof, nor Battelle Memorial Institute, nor any of their employees, makes any warranty, express or implied, or assumes any legal liability or responsibility for the accuracy, completeness, or usefulness of any information, apparatus, product, or process disclosed, or represents that its use would not infringe privately owned rights. Reference herein to any specific commercial product, process, or service by trade name, trademark, manufacturer, or otherwise does not necessarily constitute or imply its endorsement, recommendation, or favoring by the United States Government or any agency thereof, or Battelle Memorial Institute. The views and opinions of authors expressed herein do not necessarily state or reflect those of the United States Government or any agency thereof.

\author{
PACIFIC NORTHWEST NATIONAL LABORATORY \\ operated by \\ BATTELLE \\ for the \\ UNITED STATES DEPARTMENT OF ENERGY \\ under Contract DE-AC05-76RL01830
}

Printed in the United States of America
Available to DOE and DOE contractors from the Office of Scientific and Technical Information,
P.O. Box 62, Oak Ridge, TN 37831-0062;
ph: (865) 576-8401
fax: $(865)$ 576-5728
email: reports@adonis.osti.gov

\begin{abstract}
Available to the public from the National Technical Information Service, U.S. Department of Commerce, 5285 Port Royal Rd., Springfield, VA 22161 ph: (800) 553-6847 fax: $(703) 605-6900$ email: orders@ntis.fedworld.gov online ordering: http://www.ntis.gov/ordering.htm
\end{abstract}

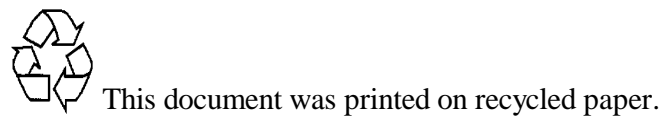




\title{
Refractory Glass Seals for SOFC
}

\author{
YS "Matt" Chou
}

JW Stevenson

July 2011

Prepared for the U.S. Department of Energy

under Contract DE-AC05-76RL01830

Pacific Northwest National Laboratory

Richland, Washington 99352 


\section{Introduction}

One of the critical challenges facing planar solid oxide fuel cell (SOFC) technology is the need for reliable sealing technology. Seals must exhibit long-term stability and mechanical integrity in the high temperature SOFC environment during normal and transient operation. Several different approaches for sealing SOFC stacks are under development, including glass or glassceramic seals, metallic brazes, and compressive seals. Among glass seals, rigid glass-ceramics, self-healing glass, and composite glass approaches have been investigated under the SECA Core Technology Program. The U.S. Department of Energy's Pacific Northwest National Laboratory (PNNL) has developed the "refractory" glass approach in light of the fact that higher sealing temperatures (e.g., 930-1000 ${ }^{\circ} \mathrm{C}$ ) may enhance the ultimate in-service bulk strength and electrical conductivity of contact materials, as well as the bonding strength between contact materials and adjacent SOFC components, such as interconnect coatings and electrodes. This report summarizes the thermal, chemical, mechanical, and electrical properties of the refractory sealing glass.

\section{Materials and fabrication}

The PNNL refractory glasses are alkaline-earth based silicate glasses fabricated by conventional glass melting processes using commercially available raw materials such as oxide and carbonate powders. The glasses contain alkaline earths ( $\mathrm{Ba}, \mathrm{Sr}, \mathrm{Ca}$, and/or $\mathrm{Mg}$ ), Y or $\mathrm{Al}$ modifiers, and $\mathrm{Si}$ and B glass formers. After evaluating a number of formulations which exhibited a wide range of thermal properties, several preferred compositions have been selected which offer sealing temperatures in the range of $930-1000^{\circ} \mathrm{C}$, and $\mathrm{CTE}$ in the $11.5-12.5 \mathrm{ppm} /{ }^{\circ} \mathrm{C}$ range.

\section{Crystal structure and thermal stability}

As noted above, the refractory sealing glasses are designed to seal at higher temperatures than conventional SOFC sealing glasses (e.g., PNNL's G18, sealing $\mathrm{T} \sim 830^{\circ} \mathrm{C}$ ). Table I shows the thermal expansion of a refractory sealing glass (YSO1, sealing $\mathrm{T} \sim 1000^{\circ} \mathrm{C}$ ) before and after an accelerated isothermal aging test at $900^{\circ} \mathrm{C}$ in air or a wet reducing environment. For comparison, the CTE behavior of G18 in air is also listed. It is apparent that the refractory sealing glass exhibited improved CTE stability compared to G18. The aged refractory glass was also characterized with $x$-ray diffraction. Figure 1 shows the diffraction patterns for refractory glass after 4, 1000, and $2000 \mathrm{hrs}$ of aging (green, blue, and red plots, respectively). It is apparent that the refractory sealing glass was very stable in terms of crystalline phase formation, as no new phases or significant changes in relative amounts of phases were observed after the initial $4 \mathrm{hr}$ heat treatment. The major phase was $\mathrm{SrSiO}_{3}$ with lesser amounts of $\mathrm{Ca}_{3} \mathrm{SiO}_{5}, \mathrm{Ca}_{2} \mathrm{SiO}_{4}$, and $\mathrm{Y}_{2} \mathrm{SiO}_{5}$ also present. The observed stability in the XRD patterns is consistent with the stability observed in the CTE measurements.

\section{Electrical stability}

Results of an electrical stability test on a representative refractory glass (YSO75, sealing $\mathrm{T}$ $\sim 975^{\circ} \mathrm{C}$ ) are shown in Figure 2. The test was performed under $0.7 \mathrm{~V}$ DC loading in dual environments at $850^{\circ} \mathrm{C} ; 850^{\circ} \mathrm{C}$ was chosen to accelerate any potential reactions. The test was run with dilute fuel $\left(2.7 \mathrm{H}_{2} / \mathrm{Ar}+30 \% \mathrm{H}_{2} \mathrm{O}\right)$ for the first $432 \mathrm{hrs}$ and then with pure $\mathrm{H}_{2}+30 \% \mathrm{H}_{2} \mathrm{O}$ for the rest of the test. The glass exhibited an electrical resistivity greater than $10^{4} \mathrm{ohm}-\mathrm{m}$, about 5 orders of magnitude higher than YSZ $\left(\sim 2.5 \times 10^{-1}\right.$ ohm-m @ $\left.800^{\circ} \mathrm{C}\right)$ and 9 orders higher than 
cathode (LSM $\sim 6 \times 10^{-5}$ ohm-m @ 800 ${ }^{\circ} \mathrm{C}$ ) or anode materials (Ni/YSZ 1x10 $0^{-5}$ ohm-m @ 800 $\mathrm{C}$ ). The high electrical resistivity clearly indicates that no significant electrical loss through the sealing glass would be expected.

\section{Volatility}

Since most of the refractory glasses contain $\sim 7-10 \mathrm{~mol} \%$ of $\mathrm{B}_{2} \mathrm{O}_{3}$ and an appreciable amount of $\mathrm{SiO}_{2}$ as the glass former, the potential weight loss, especially in reducing environments, needs to be addressed. The volatility of glass may have two impacts. First, electrochemical performance may be degraded if the volatile species deposit onto active electrochemical sites. In addition, excessive evaporation of sealing material could weaken the seal and cause leakage. Volatility of two refractory sealing glasses was evaluated in a wet reducing environment at $800^{\circ} \mathrm{C}$ for $\sim 1600$ hrs; weight loss results are shown in Figure 3. Following an initial period ( $600 \mathrm{hrs})$ of rapid weight loss, the volatility decreased significantly. The second stage volatility rates $\left(3.2-3.6 \times 10^{-8}\right.$ $\mathrm{g} / \mathrm{cm}^{2}-\mathrm{hr}$ were similar to estimated values for $\mathrm{SiO}_{2}\left(4.3-14 \times 10^{-8} \mathrm{~g} / \mathrm{cm}^{2}-\mathrm{hr}\right)$ based on published activation energies. Using the measured volatility and assuming a typical seal geometry, it is estimated that the total material loss for $40,000 \mathrm{hr}$ operation at $800^{\circ} \mathrm{C}$ would be less than 0.1 wt $\%$.

\section{Mechanical integrity}

Butt joint testing was performed to study the mechanical integrity of the refractory sealing glass. Stainless steel squares (1/2"x1/2") were joined with the sealing glass at elevated temperatures (e.g., $950^{\circ} \mathrm{C}$ ) in air. After joining, the couples were tested in uni-axial tension at room temperature. Some samples were aged in air or a wet reducing environment to study environmental effects. In addition to the as-received steel, aluminized steel coupons were also tested. The strengths are shown in Figure 4. It is evident that the seal strength degraded greatly when aged in air, while no degradation resulted from aging in a reducing environment. The loss of strength resulted from tensile residual stresses due to CTE mismatch between an interfacial reaction product $\left(\mathrm{SrCrO}_{4}, \mathrm{CTE} \sim 22 \mathrm{ppm} /{ }^{\circ} \mathrm{C}\right)$ and the other materials $\left(\mathrm{CTE} \sim 11.5-12.5 \mathrm{ppm} /{ }^{\circ} \mathrm{C}\right)$. Aluminization was effective in preventing this loss of strength during air aging.

\section{Glass validation in a single-cell stack assembly}

To further evaluate the performance of the refractory sealing glass in a realistic manner, the glass (YSO77 sealing, $\mathrm{T} \sim 950^{\circ} \mathrm{C}$ ) was tested in a single-cell stack assembly. A commercial 50mm $\mathrm{x}$ $50 \mathrm{~mm}$ anode-supported cell with LSM/YSZ cathode was tested for thermal cycle stability and baseline performance stability using $97 \% \mathrm{H}_{2}+3 \% \mathrm{H}_{2} \mathrm{O}$ vs. air at $800^{\circ} \mathrm{C}$. The cell was first sealed onto an aluminized SS441 cell frame at $950^{\circ} \mathrm{C} 2 \mathrm{~h}$ in air. The sealed couple was then assembled with SS441 anode and cathode plates, contact pastes, perimeter seals, and fuel and air heatexchangers. Figure 5 shows the open circuit voltage (OCV) versus thermal cycles. For each cycle the sample was heated from room temperature to $750^{\circ} \mathrm{C}$ in $3 \mathrm{hrs}$, held for $3 \mathrm{hrs}$, then cooled to near room temperature. The total time for each cycle was $24 \mathrm{hr}$. Throughout the thermal cycle testing, the measured OCV was very close to the theoretical Nernst potential, suggesting no fracture of the refractory sealing glass. The structural integrity of the seal was further verified during post-test analysis. Results from an electrochemical performance stack fixture test are shown in Fig. 6. This test again used refractory sealing glass for the cell-to-frame frame. Overall, the $\sim 1400 \mathrm{hr}$ test showed very good stability in electrochemical performance, with degradation (calculated from observed power density after $300 \mathrm{hr}$ ) about 1.3\%/1000 hr. The final 
OCV before terminating the test was 1.089V (@800 $\mathrm{C}$ ), suggesting that good sealing was achieved for the entire test.

\title{
Post-test interfacial analysis
}

Figure 7 shows the sealing glass/YSZ interfacial region of a cell tested in the stack test fixture. Clearly there are reactions between the sealing glass and YSZ electrolyte as demonstrated by "needle" formation along the interface. Thermodynamic calculations indicated the formation of $\mathrm{BaZrO}_{3}$ or $\mathrm{SrZrO}_{3}$, which was consistent with EDS chemical analysis. The presence of the needles is not expected to be an issue, since the CTEs of the zirconates are very close to YSZ. At the interface between the glass and the aluminized AIS 441 (Fig. 8), no chromate phase was identified. An aluminum-rich band was observed at the glass/metal interface due to substantial dissolution of the alumina surface layer, but no distinct evidence of crystalline phase formation was observed.

\section{Acknowledgements}

The work described in this report was funded through the Solid-State Energy Conversion Alliance (SECA) Core Technology Program by the US Department of Energy's National Energy Technology Laboratory (NETL). Pacific Northwest National Laboratory is operated by Battelle for the U.S. Department of Energy under Contract DE-AC06-76RL01830.

\section{Contacts}

PNNL currently has several candidate refractory sealing glasses with sealing temperature ranging from $\sim 930-1000^{\circ} \mathrm{C}$. For more information, please contact:

\author{
Dr. YS Matt Chou \\ Yeong-shyung.chou@pnnl.gov \\ 509-375-2527 \\ Dr. Jeff Stevenson \\ jeff.stevenson@pnnl.gov \\ 509-372-4697
}


Table I. CTE of sealing glass before and after aging.

\begin{tabular}{|c|r|c|r|r|r|}
\hline glass & temperature & environment & before & \multicolumn{1}{|c|}{ 1000hr } & $\mathbf{2 0 0 0} \mathbf{~ h r}$ \\
\hline YSO1 & 900 & air & 11.73 & 11.51 & 11.62 \\
\hline YSO1 & 900 & wet+red. & 11.73 & 11.62 & $\mathrm{~N} / \mathrm{A}$ \\
\hline G18 & 750 & air & 12.50 & 11.10 & $\mathrm{~N} / \mathrm{A}$ \\
\hline
\end{tabular}

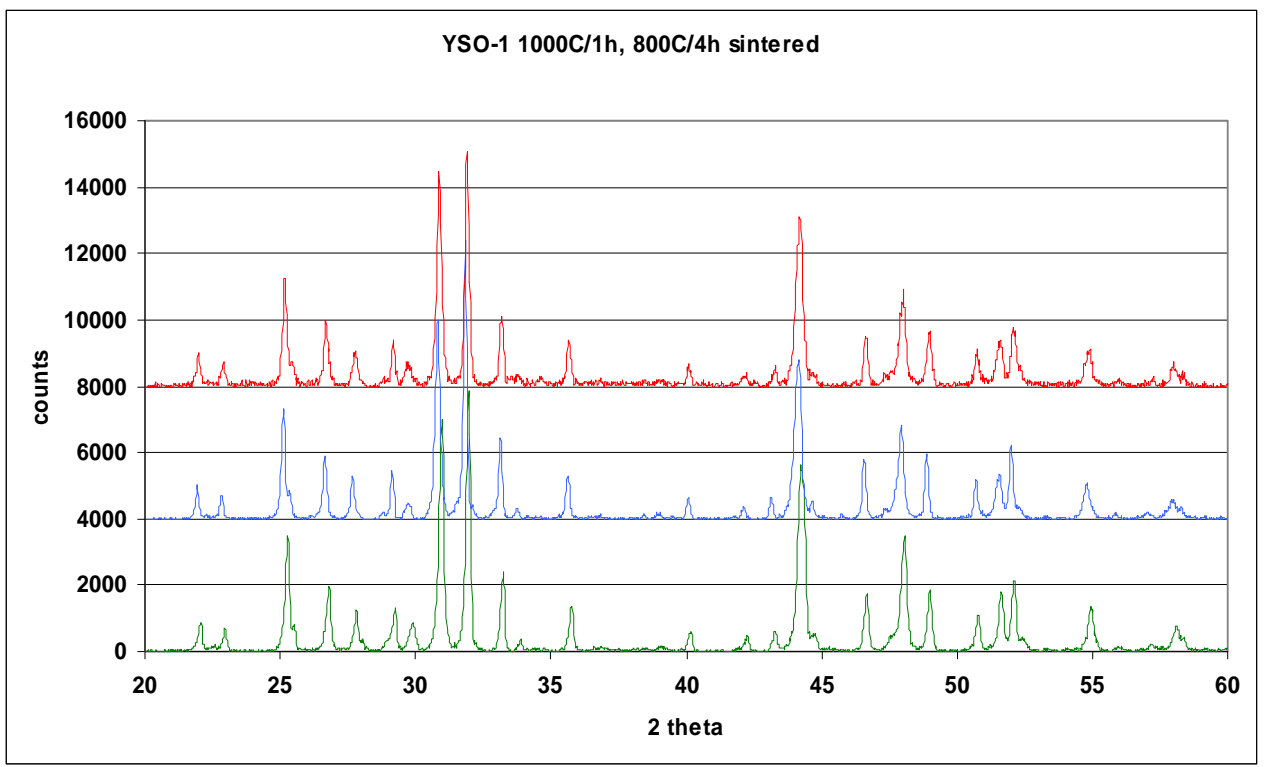

Figure 1. XRD patterns of refractory glass (YSO1) before and after accelerated aging at $900^{\circ} \mathrm{C}$.

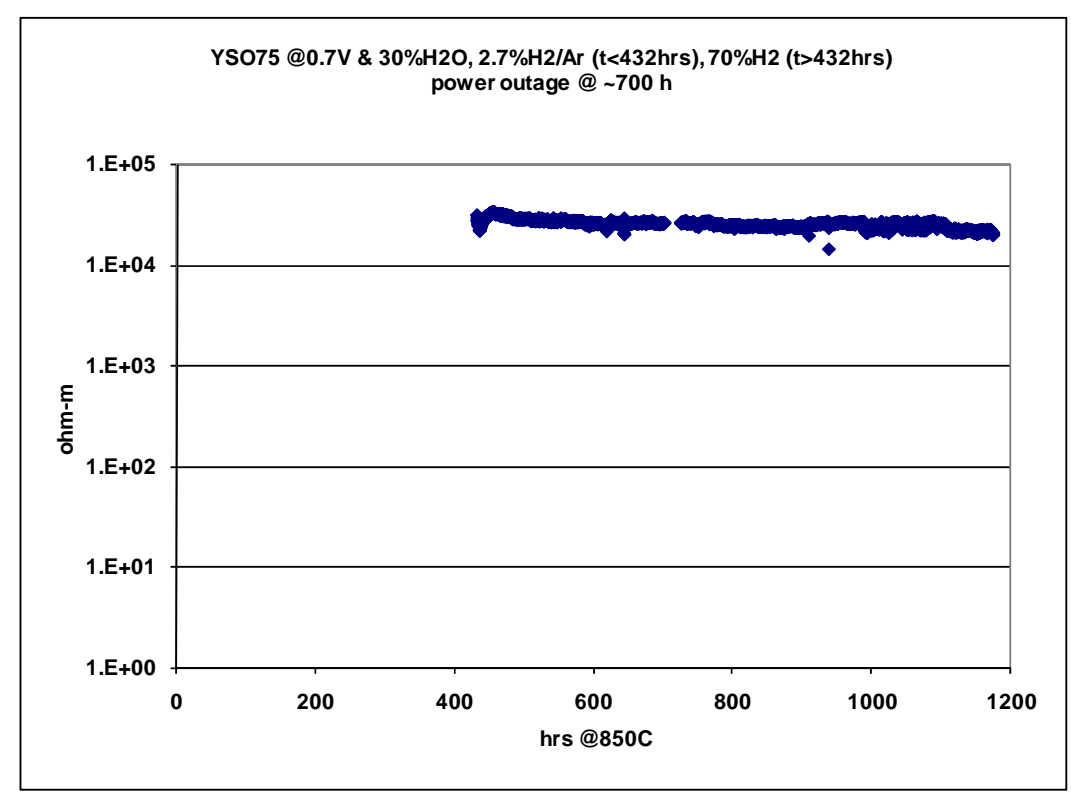

Figure 2. Electrical stability of refractory glass (YSO75) during isothermal aging under a $0.7 \mathrm{~V}$ DC loading and dual environments (pure $\mathrm{H}_{2}+30 \% \mathrm{H}_{2} \mathrm{O}$ vs. air) at $850^{\circ} \mathrm{C}$. Resistivity data were not recorded during the first $\sim 400 \mathrm{hrs}$ of the test. 


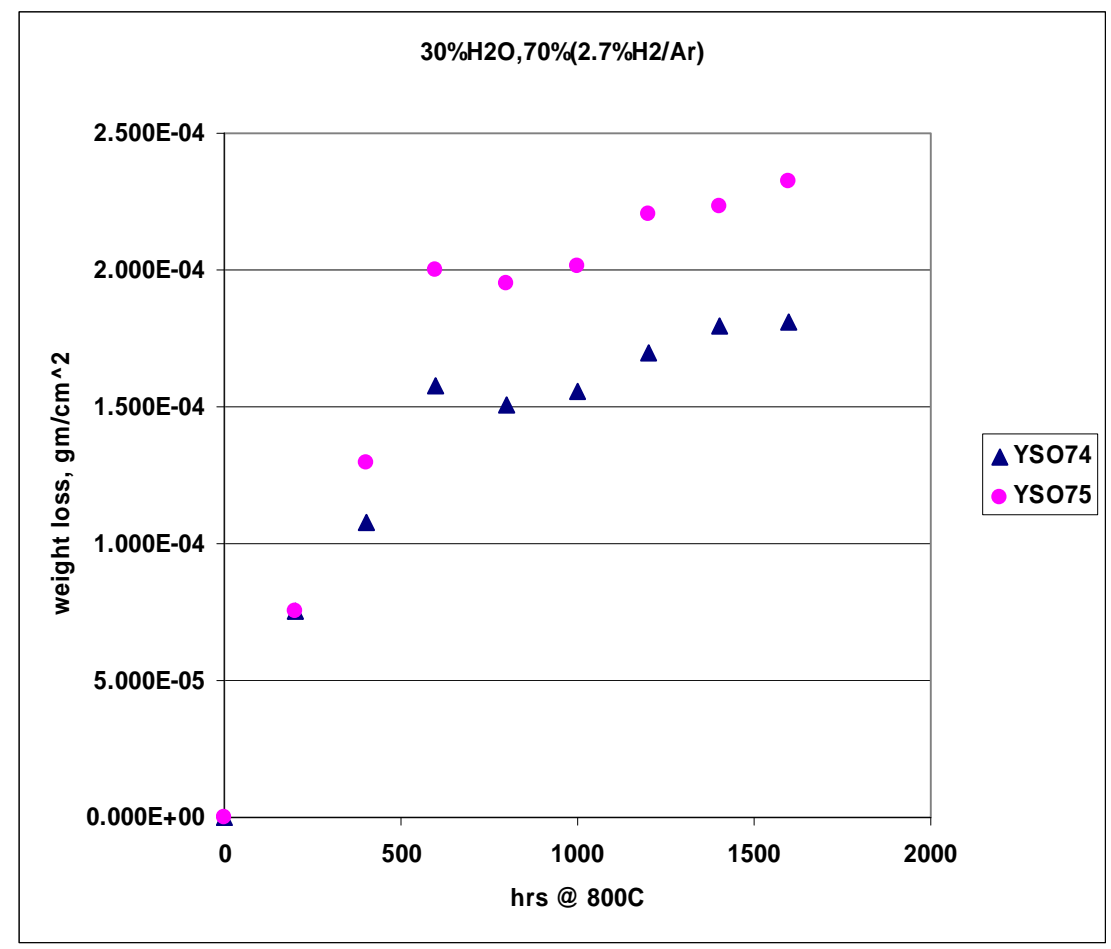

Figure 3. Weight loss versus aging time at $800^{\circ} \mathrm{C}$ in flowing wet and reducing gas $(30 \%$ $\left.\mathrm{H}_{2} \mathrm{O}+70 \%\left(2.7 \% \mathrm{H}_{2} / \mathrm{Ar}\right)\right)$ for 2 refractory sealing glasses.

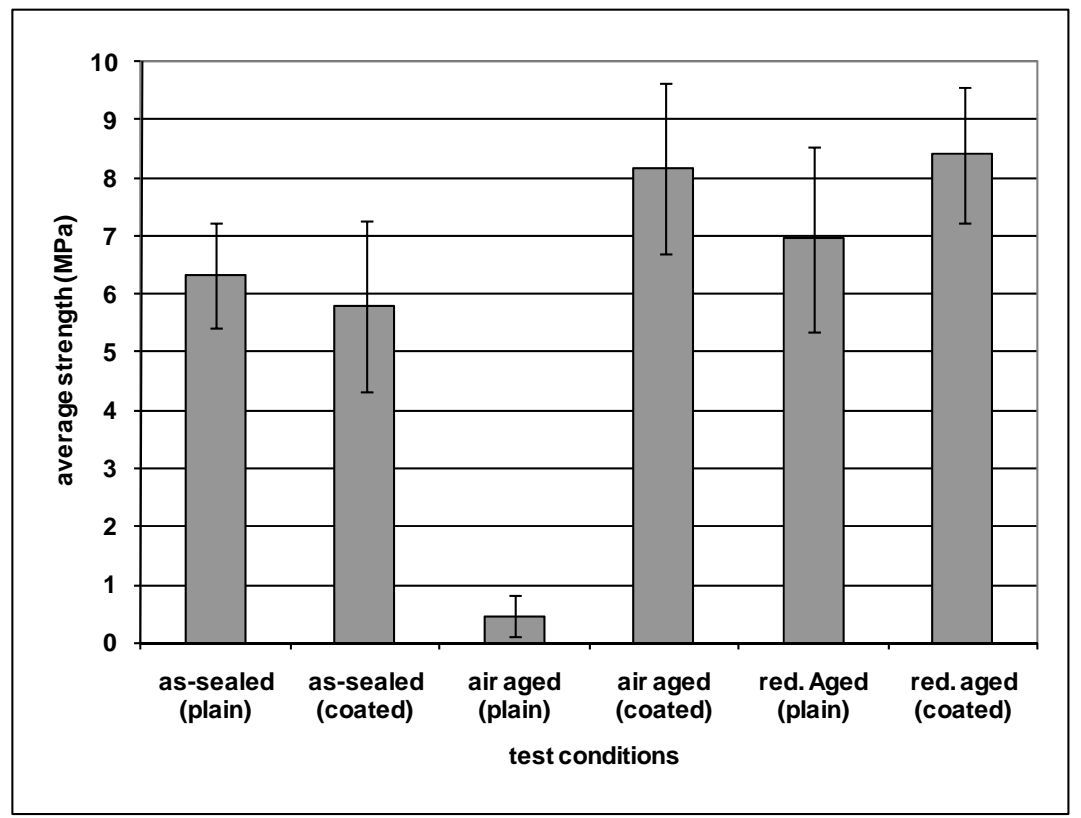

Figure 4. Effect of environmental aging on the tensile strength of joined steel/glass/steel coupons. The glass used for this test was YSO75 with sealing $\mathrm{T} \sim 975^{\circ} \mathrm{C}$. 


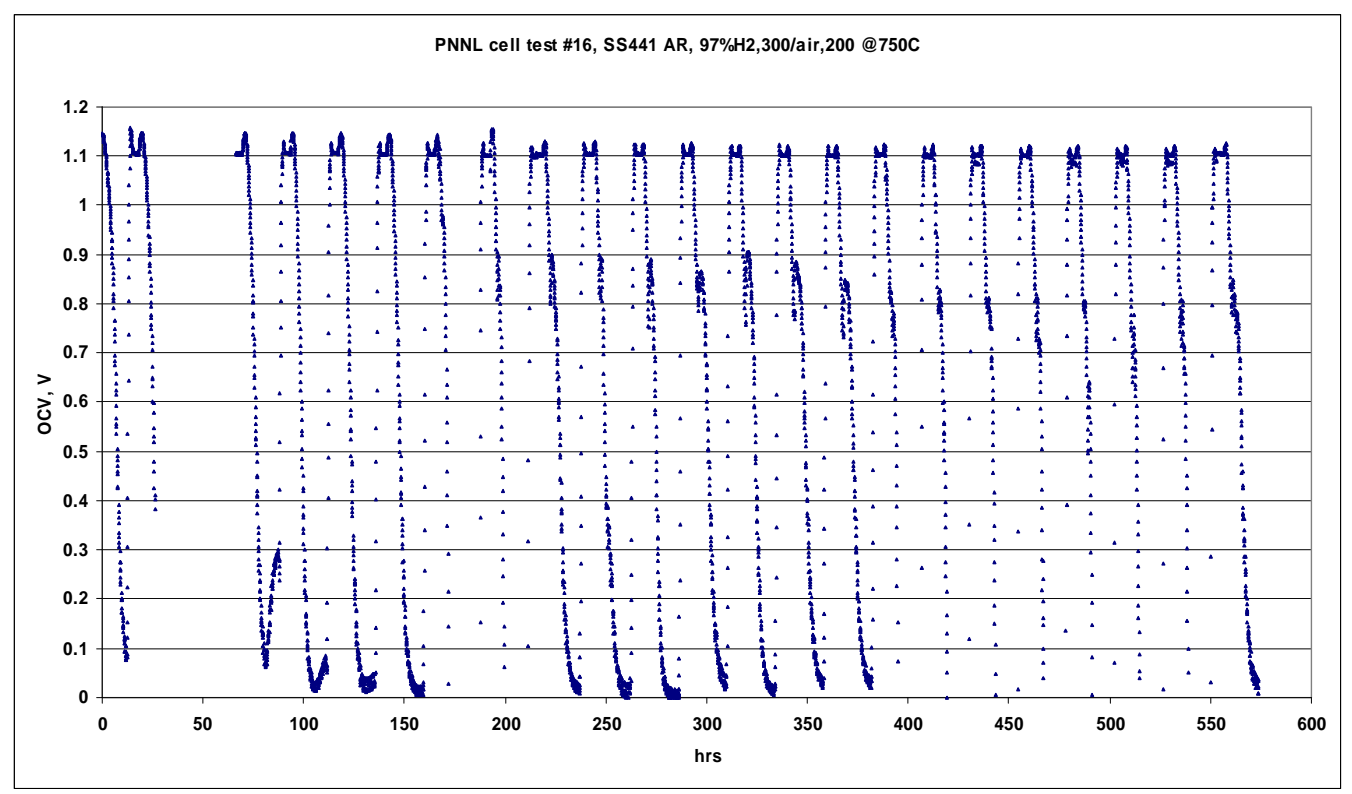

Figure 5. Thermal cycle stability test of refractory sealing glass (YSO77).

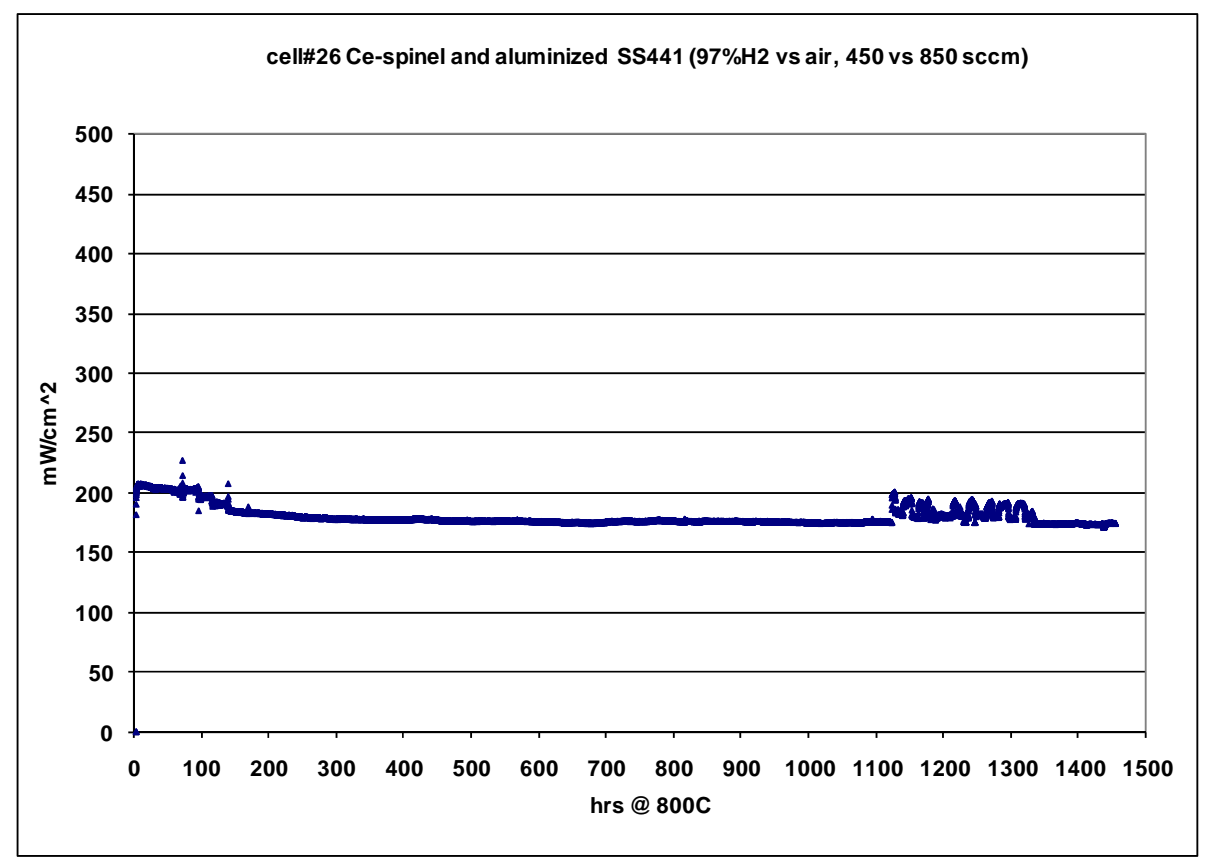

Figure 6. Electrochemical performance of anode-supported cell tested at $800^{\circ} \mathrm{C}$ and $0.7 \mathrm{~V}$ using $97 \% \mathrm{H}_{2}+3 \% \mathrm{H}_{2} \mathrm{O}$ vs. air. 


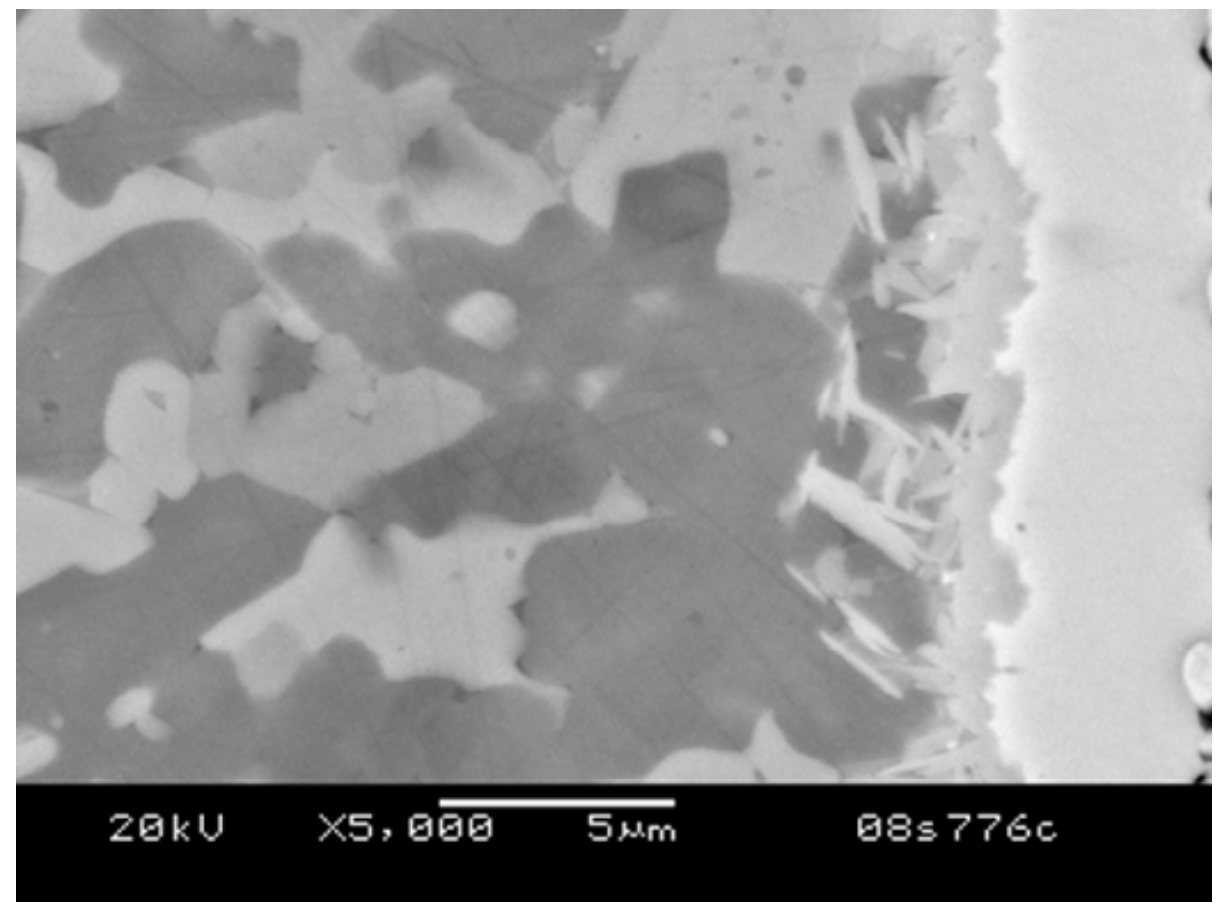

Figure 7. Interfacial microstructure along the glass/YSZ interface after $2325 \mathrm{hr}$ test at $800^{\circ} \mathrm{C}$ and $0.7 \mathrm{~V}$; YSZ is on the right.

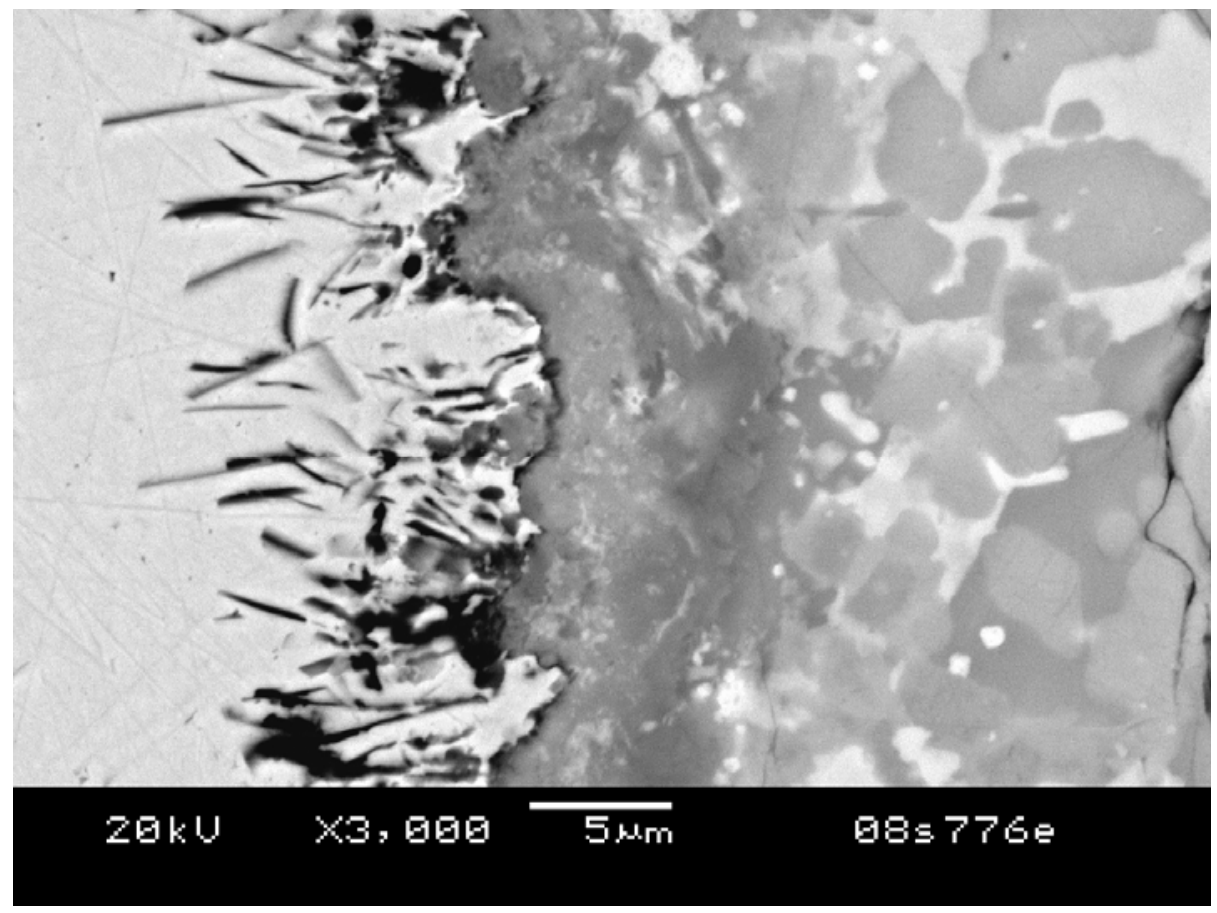

Figure 8. Interfacial microstructure along the glass/aluminized AISI 441 interface after $2325 \mathrm{hr}$ test at $800^{\circ} \mathrm{C}$ and $0.7 \mathrm{~V}$; the aluminized AISI 441 is on the left. 